\title{
ODPOWIEDZIALNOŚĆ ODSZKODOWAWCZA CZŁONKÓW ZARZĄDU SPÓŁKI Z OGRANICZONĄ ODPOWIEDZIALNOŚCIĄ BĘDĄCA KOMPLEMENTARIUSZEM SPÓŁKI KOMANDYTOWEJ WOBEC KOMANDYTARIUSZY I SPÓŁKI KOMANDYTOWEJ
}

\author{
THE RESPOSIBILITY FOR DAMAGES OF MANAGEMENT BOARD \\ MEMBERS OF THE LIMITED LIABILITY COMPANY WHICH IS THE \\ GENERAL PARTNER \\ OF THE LIMITED PARTNERSHIP
}

\begin{abstract}
Streszczenie: Popularne w polskiej praktyce gospodarczej jest tworzenie spółki komandytowej, której komplementariuszem jest spółka z ograniczoną odpowiedzialnością. Wspólnicy de facto $w$ ten sposób ograniczają swoją osobistą odpowiedzialność jaką ponosiliby, gdyby występowali w roli wspólnika aktywnego jako osoby fizyczne. Zarządzającymi spółką komandytową są członkowie spółko z o.o., których de facto nie łączy ze spółką komandytową ani komandytariuszami żaden stosunek obligacyjny. W przypadku wyrządzenia przez członków zarządu szkody spółce komandytowej bądź jej komandytariuszom pojawia się problem podstaw do odpowiedzialności. Obecny stan prawny skłania ku refleksji nad regulacją de lege ferenda nie tylko samej spółki komandytowej, ale także całego systemu prawa spółek..
\end{abstract}

Słowa kluczowe: zarząd, komplementariusz, komandytariusz, odpowiedzialność, spółka.

Received: 08.2018

\begin{abstract}
Popular in Polish business practice is the creation of a limited partnership, the general partner of which is a limited liability company. The de facto partners thus limit their personal responsibility if they acted as an active partner as natural persons. The management of a limited partnership company are members of the company with o.o., which de facto does not link with the limited partnership or limited partners any bond relationship. In the case of damage caused by members of the management board to a limited partnership or its limited partners, there is a problem of grounds for liability. The current legal situation prompts us to reflect on de lege ferenda regulation not only of the limited partnership itself, but also of the entire company law system.
\end{abstract}

Key words: Board of directors, limited partner, general partner, responsibility, partnership, company.

Accepted: 09.2018

\footnotetext{
*Uniwersytet Jagielloński Wydział Prawa i Administracji
} 


\section{Wstęp}

Rozwój gospodarki rynkowej oraz rozpowszechnienie prowadzenia działalności gospodarczej w Polsce przyczyniły się do wzrostu popularności spółek komandytowych, które teoretycznie i pierwotnie stanowiły formę prawną dla biznesu rodzinnego i to niezbyt wygórowanych rozmiarów [o dopuszczalności pisał już R. Kos, 1995, 20, T. Leipert, O. Smardzewska, 2008, 53]. Aby uniknąć odpowiedzialności, a także ze względów podatkowych, które wykraczają, a tym samym, nie będą przedmiotem niniejszego opracowania, zaczęto tworzyć spółki komandytowe, których komplementariuszem są spółki z ograniczoną odpowiedzialnością [W. Pyzioł, 2016, 123 i nast.]. Przepisy Kodeksu spółek handlowych wskazują, że odpowiedzialnym za prowadzenie spraw oraz reprezentację spółki komandytowej jest komplementariusz, czyli w przypadku omawianej konstrukcji będzie to spółka z ograniczoną odpowiedzialnością, która na mocy art. $11 \S 1$ k.s.h. jest osobą prawną. Z kolei art. 38 k.c. stanowi, że osoby prawne działają przez swoje organy, a jak wynika z art. $201 \S 1$ k.s.h. w przypadku spółki z o.o. to zarząd jest organem odpowiedzialnym za prowadzenie spraw i reprezentowanie spółki. W przypadku, gdy to spółka z o.o. jest komplementariuszem, a więc na niej spoczywa obowiązek prowadzenia spraw i reprezentowania spółki, faktyczne dokonywał będzie to zarząd spółki z o.o. De lege lata brak jest przepisu statuującego prawo, a tym bardziej obowiązek, co na gruncie przepisów regulujących spółek z o.o. zostało wyrażone w art. $208 \S 2$ k.s.h., do działania także w imieniu spółki komandytowej przez zarząd sp. z o.o. Doktryna wydaje się być zgodna, że należy w tym przypadku niejako rozszerzyć interpretację przepisów o uprawnieniu zarządu do prowadzenia spraw i reprezentowania na, także, spółkę komandytową, ponieważ odpowiedzialna za to jest spółka z ograniczoną odpowiedzialnością działająca za pomocą organów [M. Piotrowska, 2014, 234]. O ile interpretacja rozszerzająca uprawnienia zarządu nie budzi wątpliwości, o tyle gdy mówimy o obowiązkach, takie rozumienie może być wątpliwe, zwłaszcza gdy chodzić będzie o ewentualną odpowiedzialność za ich niedopełnienie [por. A. Kidyba, 2006, 177].

Zarząd spółki może być zarówno jedno-, jak i wieloosobowy, i ostatecznie to zawsze człowiek, czyli w tym przypadku członek zarządu, będzie 
decydował, a tym samym ewentualna odpowiedzialność będzie spoczywała na członku lub członkach zarządu [A. Kidyba, 2014, art. 293]. Zasadnym wydaje się także rozważenie, czy właściwsza jest odpowiedzialność wszystkich członków zarządu, w myśl zasady „jeden za wszystkich, wszyscy za jednego”, czy też indywidualna każdego, a więc implikować to będzie konieczność badania winy każdego z zarządzających [A. Szajkowski (red.).

\section{Metodologia oraz przyjęte założenia}

Na potrzeby niniejszego artykułu dokonałem swoistego podziału pojęcia odpowiedzialności członków zarządu. Pierwsza, umownie nazwana wewnętrzną, dotyczyć będzie relacji wewnątrzspółkowych. Relacje te będą obejmować stosunki zachodzące pomiędzy organem czy też członkami zarządu spółki z o.o., a komandytariuszami i samą spółką komandytową, a także, pośrednio spółką z o.o., ale tylko, gdy funkcjonalnie występować będzie jako komplementariusz. Nie będzie zatem omawiana odpowiedzialność za szkodę wyrządzoną bezpośrednio spółce z o.o., a która to jest przedmiotem regulacji art. 290 k.s.h. i nast. Odpowiedzialność wewnętrzna będzie wynikała więc z relacji zachodzących wewnątrz spółki komandytowej. A contrario odpowiedzialnością zewnętrzną nazwałem wszelką wynikającą ze stosunków z osobami trzecimi, a więc wierzycielami spółki komandytowej. Przedmiotem niniejszego opracowania będzie odpowiedzialność wewnętrzna, gdyż wydaje się, że spory korporacyjne mogą także wystąpić w spółkach hybrydowych, a zagadnienie to wydaje się niezwykle ciekawe, zwłaszcza z uwagi na fakt, że de facto spółka z ograniczoną odpowiedzialnością spółka komandytowa jest spółką osobową.

Możliwymi personalnymi wariantami przedmiotowej konstrukcji są po pierwsze, wszyscy komandytariusze są wspólnikami spółki z ograniczoną odpowiedzialnością oraz członkami zarządu tejże spółki. W tym przypadku ewentualna odpowiedzialność względem spółki komandytowej oraz komandytariuszy wydaje się wątpliwa, ponieważ de facto wspólnicy odpowiadaliby sami względem siebie. Odmienny podtyp tego wariantu przewiduje, że członkami zarządu są tylko niektórzy z komandytariuszy, co implikuje możliwość chęci dochodzenia roszczeń względem członków zarządu przez tych spośród wspólników, którzy nie zasiadają w zarządzie spółki będącej kom- 
plementariuszem. Drugi wariant przewiduje odrębność osobową pomiędzy komandytariuszami, a wspólnikami spółki z ograniczoną odpowiedzialnością. Członkowie zarządu spółki z o.o. w tym przypadku są zarazem wspólnikami tej spółki. Podobnie jak w wariancie pierwszym może także dojść do sytuacji, gdy tylko niektórzy spośród wspólników sp. z o.o. są członkami zarządu. Wariantem trzecim jest całkowita odrębność osobowa pomiędzy trzema kategoriami podmiotów w spółce komandytowej. O możliwym pociągnięciu do odpowiedzialności mówić będziemy mogli zawsze w przypadku, gdy członkami zarządu są osoby inne niż komandytariusze, a także wtedy gdy tylko niektórzy spośród komandytariuszy będą pełnić tę funkcję. W drugim przypadku pozostałym komandytariuszom, czyli niezasiadających w zarządzie spółki komplementariusza może zależeć na naprawieniu szkody wyrządzonej przez organ.

Poniżej przedstawione rozważania opierać się będą na badaniach dogmatycznych. Przedstawione zostaną najnowsze dokonania polskiej doktryny w przedmiotowej sprawie. Dokonana zostanie także analiza charakteru spółki hybrydowej, w której zderzają się cechy charakterystyczne dla spółki kapitałowej, którą jest spółka z ograniczoną odpowiedzialnością oraz spółki osobowej, czyli komandytowej. Rezultatem badań będzie próba odpowiedzi na pytanie, czy regulacja de lege lata wystarczająco chroni wspólników słabszych i samą spółkę przed działaniami wspólnika aktywnego, który działa przez organy oraz czy możliwe jest pociągnięcie do odpowiedzialności członków zarządu sp. z o.o. sp. k.

\section{Rozważania o odpowiedzialności członków zarządu sp. z o.o. sp.k.}

Jak zostało przedstawione pokrótce, spółka komandytowa, której komplementariuszem jest spółka z ograniczoną odpowiedzialnością, działa poprzez zarząd tej ostatniej. Dochodzi więc do sytuacji, w której de facto to nie wspólnik prowadzi sprawy i zarządza spółką osobową. Jest to swoiste odstępstwo od charakteru prawnego spółek osobowych, których założeniem jest personalna więź pomiędzy wspólnikami [Z. Jara, 2018, art. 1]. W ekstremalnym przypadku na stanowiska członków zarządu mogą zostać powołane osoby zupełnie obce, a mające wykształcenie odpowiednie do sprawowania funkcji zarządczych w spółce. Nie ulega wątpliwości, że sytuacja taka, z teo- 
retycznego punktu widzenia jest ekonomicznie racjonalna, ale powodować może także przeświadczenie o powinności lepszego wykonywania swojej pracy przez profesjonalistów, a to sprzyjać konfliktom wewnątrz-spółkowym. Jako pierwsza zostanie przedstawiona odpowiedzialność wewnętrzna, a następnie odpowiedzialność wobec wierzycieli za niezłożenie terminowe wniosku o upadłość.

W klasycznej nauce prawa cywilnego wyróżniamy trzy główne podstawy odpowiedzialności odszkodowawczej. Mówimy tu o odpowiedzialności kontraktowej lub deliktowej [W. Czachórski, 2003, 91]. Wydaje się, że brak jest podstaw, aby w ogóle rozważać odpowiedzialność gwarancyjną. Bardziej korzystne, z uwagi na brak konieczności wykazywania winy, jest dochodzenie roszczenia na podstawie odpowiedzialności umownej (kontraktowej). Aby można dochodzić roszczeń z tytułu umownego, konieczne jest istnienie ważnego stosunku umownego między stronami. Omawiając odpowiedzialność członków zarządu, to oni powinni być stroną umowy z komandytariuszami, lecz tak nie jest. Niewątpliwie zostaje zawarta umowa spółki, która, jak się wydaje, może być podstawą odpowiedzialności kontraktowej, tak jej stronami są komandytariusze i komplementariusze, a w omawianej sytuacji jest nią spółka z ograniczoną odpowiedzialnością. Brak jest więc zobowiązaniowego stosunku prawnego łączącego członków zarządu czy zarząd w ogólności z komandytariuszami, a nawet samą spółką komandytową. Naturalnie istnieje możliwość zawarcia określonych umów pomiędzy poszczególnymi podmiotami uczestniczącymi w ramach spółki komandytowej, lecz będą owe umowy wykraczały poza ramy typowej spółki. Taka konstrukcja i brak możliwości bezpośredniego dochodzenia roszczeń od członków zarządu nie wyklucza możliwości zażądania naprawienia szkody od spółki z o.o. Jak zostało przedstawione, spółka z o.o. jest wspólnikiem spółki komandytowej, zatem niewątpliwie strony łączy stosunek obligacyjny [A. Klein, 2005, 17]. W literaturze wskazuje się, że strony zawierając umowę spółki, zobowiązują się do dążenia do osiągnięcia określonego w umowie celu gospodarczego. Działanie na szkodę bądź zaniechanie działań służących przedsięwzięciu mogą stanowić naruszenie tego obowiązku, ponieważ albo w ich konsekwencji osiągnięcie wspólnego celu określonego w umowie stanie się utrudnione bądź nawet niemożliwe. Zastanowić się należy, czy pociągnięcie do odpowiedzialności 
spółki-komplementariusza może mieć wpływ na pośrednią odpowiedzialność członków zarządu [A. Szajkowski, 2016, s. 386 i nast.].

Niewątpliwie dobra kondycja finansowa spółki komandytowej leży w interesie jej wspólników, ponieważ osiągają z tego tytułu korzyści majątkowe. Nawet w sytuacji, kiedy postanawiają nie wypłacać wypracowanego zysku, zastosowanie znajdzie art. 53 w zw. z art. 103 § 1 k.s.h. i wspólnik otrzyma odsetki, które będą proporcjonalnie większe, im zysk jest wyższy. W sytuacji, w której spółka komandytowa ponosi stratę, także pośrednio sytuacja wspólników jest pogorszona, ponieważ nie mogą liczyć na zysk, który byłby im należny, gdyby spółka była lepiej zarządzana bądź podejmowane by były lepsze decyzje w przedmiocie strategii i jej działalności. W omawianej konstrukcji, jednym ze wspólników jest spółka z o.o., która naturalnie także pośrednio ponosi stratę, a wiec istnieje możliwość zastosowania art. 293 k.s.h [W. Czachórski, 2003, 149].

Jak zostało wskazane, to wspólnik, a więc spółka z o.o. będzie odpowiedzialna za szkodę wyrządzoną spółce komandytowej czy też komandytariuszom [zob. też I. Weiss, 1994, 17 i nast.]. Podstawą takiej odpowiedzialności będzie mogła być umowa spółki, a więc zastosowanie znajdą przepisy art. 471 i nast. Kodeksu cywilnego. Jest to sytuacja o tyle korzystniejsza dla poszkodowanego, że nie musi wykazywać winy dłużnika. Jeżeli komandytariusze wystąpią z roszczeniem odszkodowawczym przeciwko spółce z o.o. niewątpliwie ta poniesie stratę w postaci sumy, którą będzie musiała zapłacić tytułem odszkodowania. Nie trudno wykazać, że będzie to strata poniesiona przez spółkę z o.o. Jak się wydaje, jest to podstawa do wniesienia powództwa na podstawie art. 293 k.s.h. Konstrukcję, na podstawie której wierzyciel najpierw dochodził będzie roszczeń od spółki, która następnie na zasadzie swoistego regresu będzie dochodziła odszkodowania od członków zarządu, można nazwać kaskadową. Jest to jednak procedura dość długa, ponieważ, aby w ogóle wytoczyć zasadne powództwo z art. 293, będzie musiało być prawomocnie zakończone postępowanie przeciwko spółcekomplementariuszowi.

Zastanowienia wymaga, czy istnieje jakakolwiek możliwość bezpośredniego pociągnięcia do odpowiedzialności członków zarządu przez komandytariuszy. W literaturze wskazuje się, że przepisem umożliwiającym takie rozwiązanie jest art. 300 k.s.h. Wskazuje się, że komandytariusze są 
osobami trzecimi w rozumieniu przywołanego przepisu, bowiem regulacja dotyczy spółki, z o.o., wobec której niewątpliwie osoby mające status komandytariusza są osobami spoza samej spółki, a łączą ich jedynie relacje umowne w postaci umowy spółki komandytowej.

Bliższe zgłębianie przedstawionej koncepcji wydaje się jednak daremne, bowiem art. 300 nie stanowi samodzielnej podstawy odpowiedzialności. Wskazuje się, że został wprowadzony, aby rozwiać wątpliwości co do możliwości ponoszenia odpowiedzialności na zasadach ogólnych, oprócz tych, które wynikają z przepisów Kodeksu spółek handlowych [M. R. Podświadek, $2001,7]$. Przepis art. 300 k.s.h. odsyła nas więc do przepisów Kodeksu cywilnego. Stąd, możliwymi podstawami będzie art. 471 k.c., który jak już zostało przesądzone, nie znajdzie zastosowania w omawianym kazusie, oraz art. 415 k.c.

Drugą możliwością jest dochodzenie roszczenia na podstawie art. 415 k.c. Jak się wskazuje w literaturze, aby roszczenie było skuteczne, wierzyciel musi wykazać zawinione i bezprawne działanie [E. Łętowska, 2012, 12 i nast.]. Sytuacja wierzyciela jest o tyle mniej korzystna w stosunku do odpowiedzialności kontraktowej, że musi wykazać winę podmiotu, który szkodę wyrządził. Pokrótce przedstawione zostaną poszczególne elementy konieczne do przesądzenia o możliwości pociągnięcia do odpowiedzialności deliktowej [zob. E.Gniewek, P. Machnikowski, 2013, art. 415].

Powszechnie w doktrynie cywilistycznej uważa się, że zachowanie może polegać na działaniu lub zaniechaniu. Jak się wydaje, w przypadku działania zarządu zaistnieć może dojść zarówno do pierwszego, jak i drugiego wariantu działania bezprawnego. Wyrządzenie szkody poprzez działanie wydaje się oczywiste. Będzie miało miejsce, gdy zarząd celowo lub przez swoje niedbalstwo, na przykład niedostateczne zorientowanie w temacie, podejmie uchwałę o dokonaniu określonej treści, która nie będzie dla spółki korzystna. Z zaniechaniem możemy mieć do czynienia wyłącznie wtedy, gdy na podmiocie spoczywał obowiązek dokonania określonych czynności. W przypadku prowadzenia spraw spółki oraz jej reprezentowania przez członków zarządu, obowiązek taki wynika z treści art. 208 § 2 k.s.h. Szkoda może przybrać formę zarówno damnum emergens jak i lucrum cessans [A. Olejniczak, 2018, 89]. To znaczy, że za szkodę w rozumieniu art. 415 k.c. będzie uznana zarówno bezpośrednio wyrządzona spółce szkoda, która przybierze postać obo- 
wiązku naprawienia szkody, zobowiązania przewyższającego korzyść uzyskaną z danej transakcji, ale także utracone korzyści, które mogły być osiągnięte, gdyby zarząd podejmował dobre ekonomicznie decyzje. Kwestia adekwatnego związku przyczynowego w literaturze wywołuje największe kontrowersje. Rozstrzyganie nad poprawnością, bądź falsyfikacja poszczególnych teorii wykracza poza zakres niniejszego opracowania, a dla uproszczenia wywodu przyjęta zostanie ta najbardziej popularna. W literaturze wskazuje się, że dominującym jest pogląd o teorii oceny adekwatnej [Olejniczak (red.) 2018, 135]. Zgodnie z nim należy ocenić prawdopodobieństwo, z jakim wystąpiłby skutek, gdyby działanie nie zostało podjęte. Jak się wydaje, w przypadku działania członków zarządu, wystąpienie związku przyczynowego nie budzi większych wątpliwości, bowiem to samo zachowanie w postaci podjęcia złych, niekorzystnych decyzji, będzie dla spółki szkodliwe. Podobnie sytuacja będzie przedstawiała się z zaniechaniem, bowiem to brak podejmowania działań może również doprowadzić spółkę do poniesionej szkody.

Możliwym jest także rozwiązanie, na podstawie którego komandytariusze dochodzić będą odszkodowania od spółki z o.o., czyli wspólnika na podstawie deliktowej, a podstawą będzie art. 416 k.c. Posunięcie takie nie wyklucza możliwości pociągnięcia do odpowiedzialności członków zarządu z tytułu czynu niedozwolonego, na podstawie art. 415 k.c., lecz rozwiązanie takie jest wskazane niejako na marginesie, ponieważ nie traktuje bezpośrednio o odpowiedzialności członków zarządu.

\section{Wnioski}

Na gruncie obecnie obowiązujących przepisów brak jest podstaw do stwierdzenia o możliwości bezpośredniego pociągnięcia do odpowiedzialności kontraktowej członków zarządu spółki- komplementariusza przez komandytariuszy. Nie ma żadnego „łącznika” umownego pomiędzy organem spółki z ograniczoną odpowiedzialnością, a samą spółką komandytową czy też jej pozostałymi wspólnikami. Nawet przesądzenie o możliwości stosowania art. 300 k.s.h. nie poprawia sytuacji wierzycieli, gdyż ten jedynie odsyła do przepisów ogólnych Kodeksu cywilnego.

Komandytariuszom przysługują dwie możliwością. Pierwszą jest „kaskadowe" dochodzenie odpowiedzialności członków zarządu poprzez po- 
zwanie spółki z o.o., która to, gdy poniesie szkodę, będzie w następstwie tego mogła do odpowiedzialności pociągnąć członków zarządu na podstawie przepisów regulujących spółkę z ograniczoną odpowiedzialnością. Druga to dochodzenie roszczeń na podstawie art. 415 k.c., który stanowi odpowiedzialność deliktową. Ta nie jest korzystna z uwagi na konieczność wykazywania winy. Zasadnym wydaje się postulat o potrzebie uregulowania kwestii odpowiedzialności zarządzających spółką hybrydową.

Rozważania na temat ewentualnej ewolucji polskiego prawa spółek powinny objąć swoim zakresem nie tylko ewentualną regulację prawa holdingowego, ale także problematykę spółek hybryd. Na przykładzie konstrukcji spółki komandytowej, której komplementariuszem jest spółka z ograniczoną odpowiedzialnością wyraźnie widać że dochodzi do swoistego konfliktu pomiędzy charakterem prawnym spółki osobowej i spółki kapitałowej. Zasadnym wydaje się odpowiednia nowelizacja Kodeksu spółek handlowych, która wprowadziłaby regulacje dotyczące relacji pomiędzy zarządcami spółki, a wspólnikami, którzy nie mają realnego wpływu na jej działalność i funkcjonowanie.

\section{Bibliografia}

Czachórski W. (red.), Zobowiązania. Zarys wykładu, Warszawa 2003.

Gniewek E., Machnikowski P. (red.) Kodeks cywilny. Komentarz, Warszawa 2013.

Jara Z. (red.), Kodeks spółek handlowych. Komentarz, SIP Legalis 2018.

Kidyba A. Atypowe spółki handlowe, Kraków 2006.

Kidyba A., Kodeks spółek handlowych. Komentarz. SIP Legalis 2018.

Klein A., Elementy zobowiązaniowego stosunku prawnego, Wrocław 2005.

Kos R., Spółka komandytowa z udziałem spółki z o.o. jako komplementariusza na gruncie Kodeksu handlowego, Kraków 1995.

Leiperd T., Smardzewska O., Czy polska odmiana niemieckiej spółki GmbH \& Co. KG może stać się równie popularna?, PPH 2008/3

Łętowska E. (red.), System Prawa Prywatnego, tom 5, Warszawa 2012.

Olejniczak A. (red.), System Prawa Prywatnego, tom 6, Warszawa 2018. 
Piotrowska M., Odpowiedzialność cywilna komplementariusza będącego spółką z ograniczoną odpowiedzialnością i członków jego zarządu w spółce komandytowej, Wrocław 2014.

Podświadek M. R., Spółka z ograniczoną odpowiedzialnością jako komplementariusz spółki komandytowej, PPH 2001/10.

Pyzioł W., Szumański A., Weiss I, Prawo spółek, Warszawa 2016.

Pyzioł W., Kodeks spółek handlowych. Komentarz, Warszawa 2008.

Szajkowski A., System Prawa Prywatnego, Warszawa 2016.

Weiss I., Cywilnoprawna odpowiedzialność spółki z ograniczoną odpowiedzialnością i innych osób wobec jej wierzycieli, PPH 1994/10. 